Acta Universitatis Nicolai Copernici • Pedagogika XXXIX/1/2020

Nauki Humanistyczno-Społeczne • Zeszyt 451

DOI: http://dx.doi.org/10.12775/AUNC_PED.2020.008

\author{
Szymon Wójcik \\ Instytut Stosowanych Nauk Społecznych \\ Uniwersytet Warszawski \\ Fundacja Dajemy Dzieciom Siłę \\ https://orcid.org/0000-0002-3540-481X
}

\title{
ZAGROŻENIA INTERNETOWE DLA MLODZIEŻY - KLASYFIKACJA, SKALA WYSTĘPOWANIA W Polsce oraz profilaktyka
}

\section{Internet Threats for Young People - Classification, Prevalence Rate in Poland and Prevention}

\begin{abstract}
Streszczenie
W dobie pandemii i przedłużonej edukacji zdalnej szczególnego znaczenia nabiera kwestia bezpieczeństwa młodzieży w Internecie. Na podstawie literatury międzynarodowej artykuł przedstawia klasyfikację zagrożeń internetowych opartą na modelu 4C, a następnie analizowane są cztery najczęściej pojawiające się $\mathrm{w}$ debacie publicznej kwestie: kontakt $\mathrm{z}$ pornografią internetową, seksting (przesyłanie przez młodzież materiałów intymnych), cyberprzemoc (przemoc rówieśnicza z użyciem mediów elektronicznych), nadużywanie Internetu. Dla każdego z tych zagrożeń przyjęto następujący schemat: zdefiniowanie problemu, ocena skali jego występowania w Polsce na podstawie najnowszych dostępnych danych, wybrane propozycje profilaktyczne.

Słowa kluczowe: zagrożenia online dla młodzieży, edukacja medialna, pornografia, seksting, cyberprzemoc, przemoc rówieśnicza, uzależnienie od Internetu, nadużywanie Internetu
\end{abstract}




\begin{abstract}
In the time of COVID-19 pandemic and prolonged remote education, the issue of youth safety online is of particular importance. Building on international literature, the article presents the classification of internet threats based on the 4Cs model, and then analyses in detail four issues most frequent in the public debate: exposure to online pornography, sexting (sending intimate materials among young people), cyberbullying (peer violence with the use of electronic media) and internet overuse (internet addiction). The following scheme was adopted for each of them: defining the problem, assessing the scale of its prevalence in Poland on the basis of the latest available data and selected prevention proposals.
\end{abstract}

Keywords: online threats for young people, media education, pornography, sexting, cyberbullying, peer violence, internet addiction, internet overuse

\title{
Wstęp
}

wiatowa pandemia koronawirusa, która rozpoczęła się na począt$\checkmark$ ku 2020 roku, przeniosła niemal całą aktywność edukacyjną młodych ludzi do przestrzeni sieciowej. Ze względu na zagrożenia związane z kontaktami międzyludzkimi także ich nieformalna komunikacja ze znajomymi czy przyjaciółmi przeniosła się w całości do Internetu. Ucząca się młodzież jest jedną z grup społecznych najsilniej dotkniętych ograniczeniami związanymi z pandemią. Nie pozostaje to bez wpływu na ich dobrostan i kondycję psychiczną. Na podstawie badań przeprowadzonych we wrześniu 2020 r. stwierdzić można, że podczas pandemii co trzeci $(33,4 \%)$ młody człowiek w wieku $13-18$ lat nie był zadowolony ze swojego życia, a najbardziej doskwierał im brak kontaktu z rówieśnikami ${ }^{1}$.

O ile od wielu lat zwraca się uwagę na dużą rolę środowiska internetowego jako przestrzeni życia młodych ludzi, o tyle w dobie pande-

${ }^{1}$ K. Makaruk, J. Włodarczyk, R. Szredzińska, Negatywne doświadczenia młodzieży $w$ trakcie pandemii. Raport z badań ilościowych, Warszawa 2020. 
mii dla wielu młodych osób, pozbawionych na ponad rok dostępu do stacjonarnej szkoły, Internet stał się jedynym polem aktywności społecznej. Zwróciło to w większym stopniu uwagę rodziców, nauczycieli i opinii publicznej na potencjalne zagrożenia związane z długotrwałym funkcjonowaniem w środowisku online. Daje również nadzieję, że w przyszłości edukacja w większym niż dotychczas stopniu będzie przygotowywała młodzież do funkcjonowania w tym środowisku

Dotychczas dyskurs dotyczący zagrożeń młodych ludzi w sieci jest z jednej strony nazbyt uproszczony i zabarwiony nutą „paniki moralnej" (mit złotego wieku z młodymi ludźmi na podwórkach, skonfrontowany ze współczesnymi nastolatkami zamkniętymi w swoich pokojach przy ekranach) $\mathrm{z}$ drugiej prezentowany w sposób nieuporządkowany.

Temat jest z pewnością bardzo złożony. Zajmujący się nim przedstawiciele nauk społecznych powinni po pierwsze porządkować pojęcia i zjawiska, po drugie pokazywać odpowiedni obraz rzeczywistości bazujący na dostępnych danych badawczych. Na tym fundamencie należy z kolei opierać działania profilaktyczne i interwencyjne. Zgodnie z tymi założeniami celem artykułu jest po pierwsze przedstawić klasyfikację potencjalnych zagrożeń, po drugie przybliżyć wybrane zagadnienia i przedstawić skalę ich występowania a następnie przedstawić wybrane odpowiedzi pedagogiczne i profilaktyczne. W artykule zostały wykorzystane najnowsze dostępne badania, tak aby pokazać możliwie aktualny stan wiedzy w każdym z prezentowanych tematów.

\section{Klasyfikacja zagrożeń internetowych}

Bezpieczeństwo w Internecie to obszar niezwykle złożony i niejednorodny. Choć często omawia się go w sposób zbiorczy to trzeba mieć na uwadze, że jest to w istocie wiązka zagadnień o bardzo różnym charakterze. Pierwszym krokiem jest więc wprowadzenie typologii porządkującej kwestię zagrożeń dla młodych ludzi online.

Najbardziej znana jest typologia stworzona na potrzeby największego jak dotąd europejskiego projektu badawczego dotyczącego zagro- 
żeń dla dzieci online - EU Kids Online ${ }^{2}$ znana pod nazwą 3C i adaptowana także przez polskich autorów ${ }^{3}$. Typologia ta opierała się z jednej strony na trzech poziomach interakcji młodych osób w sieci (odbiór treści dostępnych w sieci - content, zawieranie kontaktów z dorosłymi użytkownikami - contact, oraz interakcja z rówieśnikami - conduct), z drugiej wskazywała na trzy obszary tematyczne zagrożeń: (1) seks, (2) agresja, (3) naruszanie innych wartości (takich jak zdrowie czy szacunek dla drugiego człowieka). Po dekadzie badań zespół Sonii Livingstone rozszerzył w $2021 \mathrm{r}$. tę typologię do postaci 4C - kolejnym wymiarem jest contract, czyli kwestia wyzyskiwania, przede wszystkim komercyjnego, przez podmioty instytucjonalne, takie jak globalne korporacje $^{4}$. Miało to związek ze zmianami samej sieci internetowej, która na przestrzeni ostatnich lat w coraz większym stopniu ulega monopolizacji przez nielicznych globalnych graczy, i w której pojedynczy użytkownik jest coraz mniej chroniony. Ten ostatni obszar jest w rodzimej literaturze poruszany stosunkowo najrzadziej i z nielicznymi wyjątkami nie doczekał się jeszcze wyczerpujących opracowań.

2 S. Livingstone, L. Haddon, A. Görzig, K. Olafsson, EU kids online II. Final report, Londyn 2011. Internet: http://eprints.lse.ac.uk/39351/1/EU_kids_online_ final_report_\%5BLSERO\%5D.pdf (dostęp: 15.07.2021 r.).

3 Por.: J. Pyżalski, Agresja elektroniczna i cyberbullying jako nowe ryzykowne zachowania młodzieży, Kraków 2012. J. Włodarczyk, Zagrożenia związanie z korzystaniem z internetu przez młodziė̇. Wyniki badania EU NET ADB, „Dziecko krzywdzone. Teoria, badania, praktyka”, 2013 nr 12(1), s. 49-68.

4 s. livingstone, m. stoilova, the 4cs: classifying online risk to children, hamburg 2021. https://doi.org/10.21241/ssoar.71817. internet: https://www.ssoar.info/ ssoar/bitstream/handle/document/71817/ssoar-2021-livingstone_et_al the_4cs classifying_online_risk.pdf?sequence $=4 \&$ isallowed $=$ y\&lnkname $=$ ssoar-2021-livingstone_et_al the_4cs_classifying_online_risk.pdf (dostęp: 15.07.2021 r.). 
Tabela 1

Typologia zagrożeń dla dzieci online (4C's classification)

\begin{tabular}{llll}
\hline & \multicolumn{1}{c}{ Seks } & \multicolumn{1}{c}{ Agresja } & \multicolumn{1}{c}{ Inne wartości } \\
\hline $\begin{array}{l}\text { Treści (content) - } \\
\text { dziecko jako odbior- } \\
\text { ca treści }\end{array}$ & $\begin{array}{l}\text { Pornografia, prze- } \\
\text { kazy seksualizujące, } \\
\text { opresyjne komu- } \\
\text { nikaty dotyczące } \\
\text { wyglądu ciała }\end{array}$ & $\begin{array}{l}\text { Treści ukazujące } \\
\text { przemoc, treści } \\
\text { rasistowskie, niena- } \\
\text { wistne }\end{array}$ & $\begin{array}{l}\text { M.in. dezinformacja, } \\
\text { fałszywe wiadomo- } \\
\text { ści, treści nieade- } \\
\text { kwatne do wieku }\end{array}$ \\
\hline $\begin{array}{l}\text { Kontakty (contact) - } \\
\text { dziecko jako odbior- } \\
\text { ca działań dorosłych }\end{array}$ & $\begin{array}{l}\text { Uwodzenie } \\
\text { (grooming), } \\
\text { wykorzystywanie } \\
\text { seksualne }\end{array}$ & $\begin{array}{l}\text { Nękanie, stalking, } \\
\text { nadmierna kontrola }\end{array}$ & $\begin{array}{l}\text { M.in. perswazja } \\
\text { ideologiczna lub } \\
\text { manipulacja }\end{array}$ \\
\hline $\begin{array}{l}\text { Zachowania } \\
\text { (conduct) - } \\
\text { dziecko jako uczestnik } \\
\text { działań rówieśniczych }\end{array}$ & $\begin{array}{l}\text { Seksting, sextortion, } \\
\text { agresja seksualna }\end{array}$ & $\begin{array}{l}\text { Agresja elektronicz- } \\
\text { na, cyberbullying, } \\
\text { (cyberprzemoc) }\end{array}$ & $\begin{array}{l}\text { M.in. udział w szko- } \\
\text { dliwych grupach } \\
\text { online, np. samooka- } \\
\text { leczających się }\end{array}$ \\
\hline $\begin{array}{l}\text { Kontrakty } \\
\text { (contract) - } \\
\text { dziecko jako strona } \\
\text { nieuczciwych umów }\end{array}$ & $\begin{array}{l}\text { Seksualne serwisy } \\
\text { streamingowe }\end{array}$ & $\begin{array}{l}\text { Oszustwa (scams), } \\
\text { phishing, kradzież } \\
\text { tożsamości, wła- } \\
\text { mania }\end{array}$ & $\begin{array}{l}\text { M.in. hazard, nie- } \\
\text { uczciwy marketing }\end{array}$ \\
\hline
\end{tabular}

Źródło: opracowanie własne na podstawie: S. Livingstone, M. Stoilova, The 4Cs: Classifying Online Risk to Children, dz. cyt., s. 21.

W artykule omówione zostaną te zagrożenia związane z korzystaniem z Internetu przez młodzież, na których najczęściej koncentrują się praktycy i teoretycy. W odniesieniu do nich znaleźć można dane badawcze przedstawiające skale ich występowania, jak również przykłady propozycji profilaktycznych. Omówione zostaną kolejno:

1. kontakt z pornografią internetową,

2. seksting (przesyłanie intymnych zdjęć lub filmów),

3. przemoc rówieśnicza online (cyberprzemoc),

4. uzależnienie od Internetu.

Pierwsze $\mathrm{z}$ nich to obszar odbioru treści (content), dwa kolejne odnoszą się przede wszystkim do obszaru interakcji rówieśniczych (con- 
duct). Z kolei uzależnienie od Internetu jest zagrożeniem, które wiąże się z ogólnym sposobem korzystania z mediów elektronicznych, nie zaś $\mathrm{z}$ konkretnymi sytuacjami, które mogą wydarzyć się w sieci. Jest to więc zagrożenie, które wykracza ponad cytowaną typologię zagrożeń 4C.

\section{Kontakt z pornografią}

Choć pornografia jako taka nie jest w Polsce penalizowana, to prawnie zabronione jest prezentowanie treści pornograficznych małoletniemu poniżej lat $15^{5}$. Nie zmienia to niestety faktu, że materiały pornograficzne od lat są łatwo dostępne dla użytkowników w każdym wieku. Zarówno praktyka pedagogiczna, jak i dostępne dane badawcze pozwalają jednoznacznie stwierdzić, że młodzież w Polsce stosunkowo często ma kontakt $\mathrm{z}$ materiałami pornograficznymi w sieci. Nie jest to problem nowy, gdyż Internetu był używany do rozpowszechniania takich materiałów niemal od początku swojego istnienia.

Dlaczego kontakt z pornografią uznajemy za problem? Treści tego typu nie tylko kształtują fałszywe poglądy na sferę seksualności i stanowią wypaczoną edukację seksualną. Młodsze dzieci trafiają na treści pornograficzne wbrew swojej woli w momencie, kiedy nie są na nie przygotowane. Nastolatki mogą celowo poszukiwać treści o charakterze seksualnym, co jest związane z procesem dojrzewania i zaciekawieniem sferą seksualności. Trafiając na pornografię, otrzymują jednak treści, które nie tylko nie przekazują im żadnej wartościowej wiedzy o ludzkiej seksualności, lecz także mogą całkowicie wypaczyć ich postrzeganie tej sfery życia. Badania prowadzone wśród młodzieży wskazały na związek między oglądaniem filmów pornograficznych online a postrzeganiem kobiet jako obiektów seksualnych. Takie przekonania są kształtowane przez filmy, w których kobieta prawie nigdy nie jest pokazywana jako równoprawna partnerka mężczyzny, lecz niemal zawsze występuje w sytuacji podporządkowania ${ }^{6}$. Niedawana analiza do-

5 Kodeks Karny, art. 200, par. 3.

6 A. J. Bridges, i in. Aggression and sexual behavior in best-selling pornography videos: A content analysis update, „Violence against women”, 2010 tom 16 nr 10, s. 1065-1085. https://doi.org/10.1177/1077801210382866. 
wiodła, że brutalność popularnych filmów pornograficznych na przestrzeni ostatnich dwóch dekad znacznie wzrosła7.

Badania dowodzą również, że oglądanie materiałów pornograficznych może prowadzić do wczesnego podejmowania zachowań o charakterze seksualnym, zwiększać przyzwolenie na nawiązywanie przypadkowych kontaktów seksualnych oraz wpływać na angażowanie się $\mathrm{w}$ inne ryzykowne zachowania $\mathrm{w}$ tej dziedzinie, takie jak posiadanie wielu partnerów, używanie podczas seksu substancji psychoaktywnych czy uprawianie seksu analnego. Co więcej, zaobserwowano zależność między intensywnym oglądaniem pornografii a stosowaniem przemocy seksualnej ${ }^{8}$. Dodatkowo treści pornograficzne mogą być dla nastolatków źródłem nieadekwatnych wzorów wyglądu i kompleksów dotyczących własnego ciała9. Widoczny jest też związek między nałogowym oglądaniem pornografii a występowaniem problemów psychicznych i mniejszym zadowoleniem z życia ${ }^{10}$.

Badanie skali kontaktu z pornografią wśród młodzieży nastręcza różne trudności metodologiczne. Młodzi respondenci, nawet $\mathrm{w}$ anonimowych badaniach, mogą nie być skłonni do deklarowania takich aktywności. Istnieją także trudności ze zdefiniowaniem i operacjonalizacją samego pojęcia pornografii. Dodatkowo z racji delikatności tematu w Polsce nie realizowano wielu badań na ten temat w większej skali. W 2017 roku Fundacja Dajemy Dzieciom Siłę na zlecenie Ministerstwa Zdrowia przeprowadziła badania ankietowe na reprezentatywnej ogólnopolskiej próbie dzieci i młodzieży $(\mathrm{N}=3943)$ pt. „Kontakt dzieci

7 M. Gola, E. Kowalewska, K. Szymczak, Analiza zmian częstotliwości brutalnych zachowań $w$ popularnych filmach pornograficznych publikowanych między 1995 a 2019 rokiem, Warszawa, 2020.

8 M. Lim, E. R. Carrotte, M. E. Hellard, The impact of pornography on genderbased violence, sexual health and well-being: what do we know?, „J Epidemiol Community Health", 2016 tom 70 nr 1, s. 3-5. DOI: http://dx.doi.org/10.1136/jech2015-205453.

9 Z. Izdebski, K. Wąż. Zdrowie seksualne i reprodukcyjne młodzieży, „Zdrowie Publiczne i Zarządzanie", 2014 tom 12 nr 1, 2014.

10 J. Peter, P. M. Valkenburg, The use of sexually explicit internet material and its antecedents: A longitudinal comparison of adolescents and adults, „Archives of Sexual behavior" 40.5, 2011, s. 1015-1025. 
i młodzieży z pornografią"11. Badania wykazały, że 43 procent dzieci i nastolatków w wieku 11-18 lat miało kontakt z materiałami pornograficznymi i seksualizującymi ${ }^{12}$. Im starsza grupa wiekowa, tym większa była skala kontaktu z pornografią. W grupie 15-16 lat było to już $55 \%$, a w najstarszej 17-18 lat - 63\%, a więc niemal dwie trzecie populacji. Dodatkowo w tej ostatniej grupie aż 50\% respondentów, którzy mieli kontakt $\mathrm{z}$ takimi materiałami, miało go co najmniej raz w tygodniu (można nazwać ich regularnymi użytkownikami). Aż 22 procent wszystkich młodych internautów w wieku 13-18 lat oglądało materiały pornograficzne zawierające agresję słowną i fizyczną. Wynik ten był zbliżony dla dziewcząt i chłopców. Badania potwierdziły także, że oglądanie treści pornograficznych może nieść za sobą negatywne skutki psychospołeczne, a także zachęcać młodych ludzi do podejmowania ryzykownych zachowań seksualnych. Osoby, które kiedykolwiek miały kontakt z pornografią, trzy razy częściej otrzymują nagie lub półnagie zdjęcia (seksting), a także pięć razy częściej je wysyłają. Natomiast ci z młodych internautów, którzy codziennie korzystają z dostępu do pornografii, dwukrotnie częściej odbywają wczesną inicjację seksualną (zanim jeszcze ukończą 15. lat). Przywołane badania z 2017 roku dowiodły również, że w Polsce większość rodziców nie stosuje żadnych zabezpieczeń na urządzeniach, do których mają dostęp ich dzieci. Badanie wykazało także, że dorośli rzadko rozmawiają z dziećmi na temat bezpieczeństwa online. Wyniki przeprowadzonych w $2018 \mathrm{r}$. badań w ramach nowej edycji międzynarodowego projektu EU Kids Online pokazały zbliżony, choć nieco niższy, odsetek 29\% młodzieży w wieku 9-16 lat ${ }^{13}$ (niższy odsetek można tłumaczyć młodszą grupą

11 K. Makaruk, J. Włodarczyk, P. Michalski, Kontakt dzieci i młodzieży z pornografią. Raport z badań. Warszawa 2017.

12 Podstawowe pytania zadane w badaniu brzmiało: „W ciągu ostatniego roku z pewnością widziałeś(-aś) wiele różnych obrazków, zdjęć czy filmów. Czasami mogły być one w sposób wyraźny związane z seksem - na przykład pokazywały nagich ludzi albo ludzi w czasie seksu. Czy w ciągu ostatnich 12 miesięcy widziałeś(-aś) cokolwiek tego typu?".

13 Ł. Tomczyk, Materiały dotyczące seksu i zjawisko sekstingu, w: Polskie badanie EU Kids Online 2018. Najważniejsze wyniki i wnioski, red. J. Pyżalski, A. Zdrodowska, Ł. Tomczyk, K. Abramczuk, Poznań, 2019, s. 140. 
wiekową badanych, pytanie zadany w obydwu cytowanych badaniach było niemal tożsame). Był to wynik zbliżony do europejskiej średniej wynoszącej $33 \%{ }^{14}$.

Badania pokazują jednoznacznie, że jest to zagrożenie internetowe, z którym powszechnie borykają się młodzi ludzie w Polsce. Intencjonalnie lub nie, większość ze starszych nastolatków, ma styczność z pornografią, co nie może pozostać obojętne dla ich rozwoju psychoseksualnego. Tymczasem temat pornografii jest wciąż w naszym społeczeństwie tematem tabu. Co za tym idzie rzadko bywa poruszany w kontekście edukacyjnym. Młodzi ludzie nie mają okazji rozmawiać o pornografii z wychowawcami, nie ma więc możliwości, aby dorośli skonfrontowali młodzież z faktami dotyczącymi tych treści i ich wpływu na psychikę. Obawy pedagogów są związane również $\mathrm{z}$ tym, że poruszanie takich tematów może wiązać się z zarzutami o promocję pornografii (np. ze strony rodziców).

Mimo tych trudności istnieją również materiały edukacyjne pozwalające na takie działania. Są to przykładowo scenariusze lekcyjne pt. „Rozumiem i wybieram”15 opracowane przez Fundację Dajemy Dzieciom Siłę w ramach projektu finansowanego przez Ministerstwo Zdrowia w wersjach dostosowanych do dwóch grup wiekowych: 11-14 lat i 15-18 lat. W wersji dla młodszych nastolatków scenariusz uświadamia, że nie wszystkie treści w Internecie są prawdziwe, a kontakt z nimi może mieć negatywny wpływ na człowieka. Uczestnicy dowiadują się również gdzie szukać odpowiedzi na nurtujące pytania z zakresu seksualności i rozwoju człowieka, aby uzyskać rzetelną wiedzę. Wersja dla starszych nastolatków porusza temat tego, jakie wartości są ważne w bliskich związkach między dwojgiem ludzi. Uczestnicy dowiadują się również, w jakim celu są tworzone materiały pornograficzne oraz

14 D. Smahel i in., EU Kids Online 2020: Survey results from 19 countries, London 2020, s. 189. https://doi.org/10.21953/1se.47fdeqj01ofo. Internet: http://eprints. lse.ac.uk/103294/1/EU_Kids_Online_2020_March2020.pdf (dostęp: 15.07.2021 r.).

15 E. Dziemidowicz, J. Klocek, M. Wojtas, Rozumiem i wybieram. Jak korzystać z zasobów Internetu, aby sobie nie zaszkodzić?, Warszawa 2017. Internet: https:// edukacja.fdds.pl/pluginfile.php/703/course/section/703/Rozumiem_i_wybieram_ Jak_korzystac_z_zasobow_internetu_aby_sobie_nie_zaszkodzic11-14_21122017_ scenariusz_zajec.pdf (dostęp: 15.07.2021 r.). 
o tym, że nie są właściwym źródłem wiedzy o seksualności, a oglądanie ich może negatywnie wpływać na ich funkcjonowanie. Problemem dostępu do pornografii dzieci i młodzieży zajmuje się również od wielu lat Stowarzyszenie Twoja Sprawa prowadzące portal opornografii.pl, na którym zamieszczane są analizy i porady dotyczące tych kwestii ${ }^{16}$.

\section{Seksting}

Z upowszechnieniem pornografii internetowej wśród młodych ludzi związana jest rosnąca popularność tzw. sekstingu. Zgodnie z przedstawioną wyżej typologią nie jest to problem z obszaru kontaktu z treściami, a raczej interakcji (głównie) rówieśniczej. Wielu autorów wskazuje jednak na relacje pomiędzy jednym a drugim zjawiskiem. Rosnąca konsumpcja pornografii prowadzi do seksualizacji kultury młodzieżowej, a dalej do normalizacji sekstingu, także w wydaniu quasi-pornograficznym ${ }^{17}$.

Seksting (ang. sexting) można zdefiniować jako przesyłanie lub publikowanie własnych intymnych zdjęć lub filmów za pośrednictwem Internetu lub telefonów komórkowych. Materiały takie bywają przesyłane pomiędzy partnerami w związkach lub wykorzystywane jako sposób na zainteresowanie chłopaka bądź dziewczyny swoją osobą ${ }^{18}$. Obecnie w literaturze spotyka się różne oceny tego zjawiska. Często ma ono charakter konsensualny i odbywa się za obopólną zgodą. Czasami jednak seksting bywa elementem przemocy seksualnej lub procesu uwodzenia małoletnich przez dorosłych (tzw. grooming). Materiały intymne mogą być uzyskane za pomocą podstępu lub nacisku. Część badaczy wprowadza tu rozróżnienie na seksting „kwalifikowa-

16 Stowarzyszenie Twoja Sprawa. Strona Internetowa: https://opornografii.pl (dostęp: 15.07.2021 r.).

17 R. Amundsen, Kind of like making porn of yourself: understanding sexting through pornography, „Feminist Media Studies”, 2019, tom 19 nr 4, s. 479-494. https://doi.org/10.1080/14680777.2018.1494617.

18 Ł. Wojtasik, Seksting wśród dzieci i młodzieży, „Dziecko krzywdzone. Teoria, badania, praktyka", 2014, tom 13 nr 2, s. 79-98. 
ny" (aggravated) i eksperymentalny (experimental) ${ }^{19}$, gdzie ten pierwszy uwzględnia złą wolę, element szantażu czy wymuszenia, ten drugi zaś mieści się bardziej w kategoriach poznawania i eksperymentowania z własną seksualnością.

Niezależnie od oceny konkretnych przejawów tego zjawiska, w każdym przypadku jest to zachowanie ryzykowne, ponieważ nigdy nie można mieć pełnej kontroli nad raz wysłanym zdjęciem bądź filmem. Materiały takie bywają przesłane dalej, wykradane bądź wykorzystywane do szantażowania lub skompromitowania przedstawionej na nich osoby. W krajach anglosaskich do języka potocznego weszło sformułowanie revenge porn - materiałów pornograficznych publikowanych w Internecie w akcie zemsty (zazwyczaj przez porzuconego partnera). W przypadku osób małoletnich ryzyko jest znacząco większe. Oprócz kwestii kompromitacji, czy utraty dobrego imienia, w grę wchodzi wtórne wykorzystanie materiałów sekstingowych jako pornografii dziecięcej. Choć kwestia od strony prawnej jest złożona, to z pewnego punktu widzenia młode osoby nagrywające samych siebie w intymnych sytuacjach wytwarzają materiały, które mogą być zaliczone do pornografii dziecięcej (tzw. self-generated sexual content) ${ }^{20}$.

Seksting to jedno ze zjawisk internetowych, które w Polsce badane jest dopiero od niedawna. Pierwsze badanie mające na celu oszacowanie skali tego zjawiska zostały przeprowadzone w roku $2014^{21}$. Przeprowadzone zostało metodą kwestionariusza internetowego wśród młodzieży w wieku 15-19 lat (CAWI, N=503). Dowiodło ono, że skala problemu jest stosunkowo duża. 45\% respondentów przyznało, że ich znajomi przesyłają tego typu materiały. Pozostała część zadeklarowała,

19 J. Wolak, D. Finkelhor, Sexting: A typology, "Durham, NH: Crimes against Children Research Center", 2011. Internet: https://scholars.unh.edu/cgi/viewcontent.cgi?article $=1047 \&$ context $=$ ccrc (dostęp: 15.07.2021 r.).

20 K. Katana, Prawne aspekty dobrowolnej aktywności seksualnej online podejmowanej przez małoletnich. „Dziecko Krzywdzone. Teoria, badania, praktyka”, 2020, tom $19 \mathrm{nr} 4$, s. 126-144.

21 S. Wójcik, K. Makuruk, Seksting wśród polskiej młodzieży. Wyniki badania ilościowego, Warszawa 2014. Internet: https://fdds.pl/_Resources/Persistent/c/c/8/f/cc8fee410093693294ae8b7fbf39b2c0d9322b41/W̄Wojcik_Makaruk_eksting_wsrod_polskiej_mlodziezy.pdf (dostęp: 15.07.2021 r.). 
że nie zna nikogo, kto tak robi. Nieco ponad jedna trzecia (34\%) przyznała, że sama otrzymała materiały sekstingowe, a co dziewiąty z nich (11\%), że sam je wysyłał. Ci, którzy otrzymywali takie wiadomości, twierdzili, że najczęściej była to próba „poderwania” (a nie flirt w ramach istniejącego związku). Stosunkowo często wiadomości takie były wysyłane nie przez osoby, które respondenci znali, ale przez obcych. Z kolei ci, którzy deklarowali wysyłanie wiadomości sekstingowych, najczęściej wysyłali je do swoich chłopaków/dziewczyn ${ }^{22}$. Nowsze badanie „Nastolatki 3.0” z roku 2016 potwierdziło dużą skalę zjawiska wskazując, że 42\% młodych ludzi w wieku 15-18 otrzymało od kogoś innego materiały intymne, a 15\% przyznało się do publikacji tego typu materiałów (przy czym pamiętać należy, że podobnie jak przy badaniach dotyczących kontaktu z pornografią skala ta może być zaniżona, ze względu na wrażliwy charakter pytania i niechęć do przyznawania się do tego typu aktywności). O seksting pytano również w przywoływanej już nowej edycji EU Kids Online przeprowadzonej w 2018 r. Tam wyniki były nieco niższe: 15\% otrzymało materiały sekstingowe, a 5\% je wysyłało ${ }^{23}$. W badaniu tym pytano jednak młodszą grupę wiekową (11-17 lat) oraz użyto pytań mogących wzbudzać wątpliwości, co do prawidłowego odczytania przez młodych respondentów ${ }^{24}$.

Podobnie jak w przypadku pornografii polska oferta edukacyjna i profilaktyczna w temacie sekstingu nie jest wystarczająca rozbudowana, jeśli porównamy ją do szerokiej skali rozpowszechnienia zjawiska. Fundacja Dajemy Dzieciom Siłę w roku 2015 udostępniła scenariusz zajęć lekcyjnych dla uczniów w wieku 13-18 lat pt. „Seksting”25. Skupia

22 Tamże.

23 D. Smahel i in. EU Kids Online 2020: Survey results from 19 countries, dz. cyt.

24 Polska wersja pytania brzmiała „Czy otrzymałeś/aś kiedykolwiek wiadomości związane z seksem”. W odbiorze szczególnie młodszych nastolatków przesyłanie nagich zdjęć niekoniecznie musi być interpretowane jako „wiadomości związane z seksem".

25 Seksting. Scenariusz zajęć dla uczniów szkół ponadpodstawowych. Fundacja Dajemy Dzieciom Siłę, 2016. Internet: https://edukacja.fdds.pl/pluginfile.php/703/ course/section/705/seksting_01_21112016_scenariusz.pdf?time=161904502853 (dostęp: 15.07.2021 r.). 
się on nie tylko na przekazaniu informacji o zjawisku i potencjalnych zagrożeniach, ale także daje okazję do przedyskutowania motywacji stojących za sekstingiem oraz możliwości pomocy gdy zaistnieją negatywne skutki sekstingu. Jednym z zasadniczych problemów jest bowiem fakt, że to ofiary sekstingu, osoby, których nagie wizerunki zostają upublicznione często są oskarżane i piętnowane, co pogłębia tylko ich trudną sytuację. Z kolei Państwowy Instytut Badawczy NASK, który także prowadzi działania na rzecz bezpieczeństwa najmłodszych użytkowników sieci publikował w 2019 r. poradnik dla rodziców pt. „Seksting i nagie zdjęcia. Twoje dziecko i ryzykowne zachowania online"26, który ma pomóc rodzicom odpowiednio reagować w trudnych sytuacjach związanych z sekstingiem.

\section{Przemoc rówieśnicza w sieci (cyberprzemoc)}

Pisząc o sekstingu, wspomniano o zagrożeniach związanych z intencjonalną publikacją kompromitujących materiałów w sieci. Tego typu zdarzenia zaliczamy do przejawów cyberprzemocy, czyli przemocy rówieśniczej w Internecie. Dla młodych ludzi cyberprzemoc jest istotnym problem, który jednak w przestrzeni publicznej jest poruszany rzadziej, niż np. kwestia dostępu młodych ludzi do pornografii. Zazwyczaj przywoływane jest w kontekście przypadków skrajnych - np. nastolatków, którzy nie mogąc wytrzymać gnębienia podejmowali próby samobójcze, jednak skala tego typu zjawisk jest ogromna i choć zazwyczaj nie kończy się tak tragicznie, ma duży negatywny wpływ na dobrostan psychiczny wielu młodych ludzi.

Zjawisko to ma na tyle złożony charakter, że trudno o jego jednoznaczną definicję i określenie precyzyjnego zakresu. Przemoc rówieśniczą w sieci w anglojęzycznej nomenklaturze określa się terminem cyberbullying. W Polsce także często używa się tej angielskiej nazwy, choć w użyciu znajduje się również używany w niniejszym artykule termin

26 A. Kwaśnik, Seksting i nagie zdjęcia. Twoje dziecko i ryzykowne zachowania online, Warszawa, 2019. Internet: https://kometa.edu.pl/uploads/publication/975/ d7d3_AA_,Sexting_i_nagie_zdjęcia”_poradnik_dla_rodziców.pdf?v2.8 (dostęp: 15.07.2021 r.). 
„cyberprzemoc”, czyli przemoc z użyciem technologii informacyjnych i komunikacyjnych (Internetu i telefonów komórkowych). Badacz zagadnienia Jacek Pyżalski idąc za niektórymi autorami zagranicznymi rozróżnia z kolei „agresję elektroniczną”, czyli pojedyncze akty przemocy w sieci i „cyberbullying” (gnębienie, nękanie w sieci), czyli działanie intencjonalne, trwające dłuższy czas, przed którym ofiara nie może się obronić ${ }^{27}$.

$\mathrm{Na}$ cyberprzemoc składają się różne rodzaje agresywnych zachowań. Podstawowe jej formy to wyzywanie, nękanie, straszenie, szantażowanie z użyciem sieci, publikowanie lub rozsyłanie ośmieszających, kompromitujących informacji, zdjęć, filmów z użyciem sieci oraz podszywanie się w sieci pod kogoś wbrew jego woli, a także wykluczanie z grupy rówieśniczej online, np. poprzez usunięcie kogoś z grona znajomych w portalu społecznościowym. Zależnie od kontekstu i używanych platform listę tę można by jeszcze wydłużać.

Badania prowadzone wśród młodzieży pokazują, że przemoc rówieśnicza występująca w sieci i poza nią są ze sobą silnie powiązane. W zdecydowanej większości przypadków osoby, będące ofiarami cyberprzemocy doświadczają także nękania poza Internetem ${ }^{28}$. Nie można zastanawiać się nad rozwiązaniem problemu cyberprzemocy abstrahując od kwestii przemocy rówieśniczej w ogóle.

Jednocześnie cyberprzemoc posiada swoją specyfikę związaną z komunikacją zapośredniczoną przez sieć. Po pierwsze, krzywdzące materiały w sieci mogą rozprzestrzeniać się z dużą szybkością i mieć większy zasięg niż jakiekolwiek formy przemocy tradycyjnej. W najgorszych przypadkach materiały wyśmiewające bądź kompromitujące daną osobę mogą stać się viralami - „przebojami” Internetu oglądanymi przez tysiące osób. Po drugie, medium internetowe wpływa na mniejsze opory u osób rozpowszechniających krzywdzące materiały (tzw. zjawisko rozhamowania). Nie mając bezpośredniej informacji zwrotnej w postaci reakcji ofiary, sprawcy są skłonni posunąć się w swoim zachowaniu

27 J. Pyżalski, Agresja elektroniczna i cyberbullying jako nowe ryzykowne zachowania młodziė̇y. Kraków, 2012.

28 Tamże. 
dalej niż w innych okolicznościach bądź w ogóle nie odbierają swojego zachowania jako krzywdzenia ${ }^{29}$.

Ofiary cyberprzemocy mogą odczuwać poważne skutki dla zdrowia psychicznego, mają wyższe ryzyko depresji, wyższą podatność na uzależnienie od alkoholu czy narkotyków, częściej doświadczają problemów z nauką, wreszcie mogą pojawić się u nich myśli lub próby samobójcze ${ }^{30}$. Wśród często występujących konsekwencji można wymienić także lęki społeczne, obniżone poczucie własnej wartości czy zaburzenia psychosomatyczne (problemy z jedzeniem, snem) ${ }^{31}$.

Istnieją duże rozbieżności $\mathrm{w}$ badaniach dotyczących przemocy w sieci. Skala zjawiska zależy w dużym stopniu od tego jakie formy agresji zostały uwzględnione $\mathrm{w}$ danym badaniu oraz czy chodzi o jednorazowe akty, czy długotrwałe nękanie. We wspomnianych już badaniach „Nastolatki 3.0” przeprowadzonych przez instytut badawczy na uczniach w wieku 14-17 lat z 2018 roku $(\mathrm{N}=1173)$ wykazano, że wyzywania w sieci doświadczyła ponad jedna czwarta $(26,8 \%)$ nastolatków. Poniżany lub ośmieszany w sieci był co piąty z nich (19,5\%). Niemal co dziewiąty $(9,1 \%)$ był szantażowany. Tyle samo - 9,2\% przyznało, ze rozpowszechniono kompromitujące ich materiały $\mathrm{w}$ sieci ${ }^{32}$. W innym niedawnym badaniu przeprowadzonym wśród uczniów klas IV-VIII $(\mathrm{N}=500)$ w roku 2020 wykazano nawet wyższą skalę cyberprzemocy, pytając o doświadczanie obraźliwych komentarzy „hejtu” (doświad-

29 J. Barlińska, D. Lalak, A. Szuster, A. Jak skutecznie ograniczyć cyberprzemoc rówieśniczą? - o efektywności metod aktywizujących kompetencje społeczne ze szczególnym uwzględnieniem empatii, „Dziecko Krzywdzone.Teoria, badania, praktyka", 2018 tom 17 nr 1, s. 68-95.

30 UNICEF, The State of the World's Children 2017: Children in a digital world, New York, 2018.

31 J. Pyżalski, Elektroniczna agresja rówieśnicza - ustalenia empiryczne ostatniej dekady, w: Uzależnienia behawioralne $i$ zachowania problemowe młodzieży, red. J. Jarczyńska. Bydgoszcz 2014, s. 34.

32 M. Bochenek i in., Nastolatki 3.0, Raport z ogólnopolskiego badania uczniów, red. M. Bochenek, R. Lange. Warszawa 2019, s. 63. 
czała go niemal jedna trzecia, 32,8\%) oraz otrzymywanie obraźliwych wiadomości (36\% respondentów) ${ }^{33}$.

Istnieją również międzynarodowe projekty badawcze mające na celu pomiar zjawiska przemocy rówieśniczej online w perspektywie porównawczej. Przywoływany już projekt EU Kids Online w edycji z 2018 r. zanotował w Polsce wskaźnik wiktymizacji cyberprzemocą na poziomie $40 \%$ a sprawstwa na poziomie $38 \%$. Te wyjątkowo wysokie wyniki plasowały Polskę na niechlubnym pierwszym miejscu zestawienia szesnastu krajów europejskich znacznie powyżej średniej (wynoszącej odpowiednio 14\% i 23\%) ${ }^{34}$. Począwszy od edycji 2013/2014 tematykę cyberprzemocy włączono również do międzynarodowego badania WHO Health Behaviour in School-aged Children (HBSC), gdzie już wcześniej znajdowały się pytania dotyczące rówieśniczej przemocy fizycznej. W najnowszej edycji realizowanej w 2018 r. badano proporcje dziewcząt i chłopców w wieku 11, 13 i 15 lat, którzy padali ofiarą cyberprzemocy (definiowanej jako wysyłanie obraźliwych wiadomości lub publikację obraźliwych treści na czyjś temat) 2-3 razy w miesiącu lub częściej. Chodziło więc o pomiar cyberprzemocy mającej powtarzalny, długotrwały charakter. W Polsce dotyczyło to 17\% jedenastolatków, 19\% trzynastolatków oraz 20\% piętnastolatków. Były to na tle międzynarodowym stosunkowo wysokie wyniki. Szczególnie dla populacji piętnastolatków nasz kraj zajął piąte miejsce na 44 badane kraje ${ }^{35}$. Należy podkreślić, że i w badaniach EU Kids Online i HBSC w najnowszych edycjach skala problemu cyberprzemocy w Polsce znacznie się zwiększyła. Ponieważ są to bardzo skrupulatnie realizowane projekty

33 K. Poszwa, D. Myślińska, Analiza zjawiska przemocy rówieśniczej - teoria i badania własne. „Dziecko Krzywdzone. Teoria, badania, praktyka”, 2020 tom 19 nr 4, s. 12-25.

34 D. Smahel i in, EU Kids Online 2020: Survey results from 19 countries, dz. cyt., s. 53.

35 Spotlight on adolescent health and well-being. Findings from the 2017/2018 Health Behaviour in School aged Children (HBSC) survey in Europe and Canada. International report. Volume 2. Key data, red. J. Inchley i in. Copenhagen 2020, s. 100-102. Internet: https://apps.who.int/iris/bitstream/handle /10665/332091/9789289055000-eng.pdf (dostęp: 15.06.2021 r.). 
badawcze o stałej metodologii, jest to istotna przesłanka do stwierdzenia, że problem cyberprzemocy w naszym kraju się pogłębia.

Jednocześnie odpowiedź edukacyjna czy pedagogiczna na problemy przemocy rówieśniczej w ogóle, a cyberprzemocy w szczególności, wydaje się dalece niewystarczająca. W naszym kraju funkcjonuje niewiele pogłębionych programów profilaktycznych mających na celu ograniczenie przemocy rówieśniczej, stosunkowo niewiele jest również organizacji pozarządowych, które koncentrowałyby się na tym zagadnieniu. Na niedostatki profilaktyki w tym obszarze zwracała uwagę m.in. Najwyższa Izba Kontroli w 2014 roku $^{36}$.

Dopiero w ostatnich latach spotkać się można z działaniami mającymi na celu zmienić ten stan rzeczy. Opublikowany w 2019 roku IMPACT (Interdyscyplinarny Model Przeciwdziałania Agresji i Cyberprzemocy Technologicznej) to propozycja programu profilaktyki cyberprzemocy skierowana do uczniów klas VI-VIII szkół podstawowych. Program został opracowany przez konsorcjum złożone z Fundacji Praesterno, Fundacji Dajemy Dzieciom Siłę z udziałem naukowców i ekspertów z zakresu psychologii (UW), pedagogiki (IMP w Łodzi) oraz bezpieczeństwa informacyjnego (PW). Składa się z cyklu dziewięciu lekcji mających formę warsztatów, podczas których młodzież pracuje nad rozwijaniem kompetencji, które przyczyniają się do ograniczenia przemocy i zwiększenia bezpieczeństwa uczniów w sieci. Oprócz scenariuszy zajęć program obejmuje podręcznik, materiały filmowe oraz prezentacje i narzędzia multimedialne ${ }^{37}$. Inną ciekawą propozycją jest również opracowany przez Uniwersytet SWPS i zespół dr Małgorzaty Wójcik program RESQL opublikowany w 2020 roku $^{38}$. Opiera się on na zestawie aplikacji mobilnych, z pomocą których uczniowie mogą zgła-

36 Przeciwdziałanie zjawiskom patologii wśród młodzieży szkolnej. Informacje o wynikach kontroli. KNO-4101 03-00/2013. Nr ewi. 43/2014/P/13/068/ KNO. Warszawa, 2014. https://www.nik.gov.pl/plik/id,6956,vp,8803.pdf (dostęp: 15.07.2021 r.).

37 IMPACT (Interdyscyplinarny Model Przeciwdziałania Agresji i Cyberprzemocy Technologicznej), Fundacja Dajemy Dzieciom Siłę. Internet: impact.fdds.pl (dostęp: 15.07.2021 r.).

38 R. Kaczan, M. Wójcik, Monitorowanie i zwalczanie przemocy w szkole RSQL, Uniwersytet SWPS. Internet: www.resql.pl (dostęp: 15.07.2021 r.). 
szać przypadki przemocy rówieśniczej, w tym cyberprzemocy do przeszkolonego nauczyciela-interwenta. Może to pomóc nie tylko rozwiązywać indywidualne problemy, ale także monitorować sytuację w całej społeczności szkolnej. Aplikacjom towarzyszy również zestaw scenariuszy lekcyjnych dotyczących profilaktyki przemocy rówieśniczej.

Aktualna sytuacja pandemii i przedłużającej się nauki zdalnej (oraz przeniesienia do sieci niemal wszystkich relacji rówieśniczych) rodzi pytania o to, czy także zjawisko cyberprzemocy nie przybiera na sile. Nie ma jeszcze dokładnych danych na ten temat, ale badania przeprowadzone w 2020 roku podsuwają pewne przesłanki potwierdzające tę tezę. W badaniach poświęconych zdalnej edukacji, aż 49\% uczniów klas VI-VIII szkół podstawowych oraz szkół ponadpodstawowych $(\mathrm{N}=1284)$ stwierdziło, że ich relacje z kolegami i koleżankami znacznie się pogorszyły ${ }^{39}$. W cytowanym już badaniu dotyczącym negatywnych doświadczeń $\mathrm{w}$ pandemii $15 \%$ młodych respondentów przyznało, że padało ofiarą przemocy rówieśniczej ${ }^{40}$. Z racji zdalnej edukacji, można domniemywać, że w ten zakres wchodziły głównie doświadczenia cyberprzemocy.

\section{Nadużywanie Internetu}

Wpływ pandemii i zdalnej edukacji na pewno jest znaczący jeśli chodzi o kolejny szeroko dyskutowany problem - nadużywanie Internetu przez dzieci i młodzież. W odróżnieniu od poprzednio omawianych jest to zagadnienie bardziej ogólnie - nie dotyczy bowiem konkretnych zdarzeń w sieci, a raczej miejsca i roli mediów cyfrowych w życiu

39 G. Ptaszek i in., Zdalna edukacja - gdzie byliśmy, dokąd idziemy? Wstępne wyniki badania naukowego „Zdalne nauczanie a adaptacja do warunków społecznych w czasie epidemii koronawirusa", Warszawa, 2020. DOI: 10.13140/RG.2.2.25737.67685. Internet: https://zdalnenauczanie.org/wp-content/uploads/2020/06/Badanie-zdalnenauczanie_org_prezentacja.pdf (dostęp: 15.07.2021 r.). Warto przy tym zaznaczyć, że badanie realizowane było w maju i czerwcu 2020, a więc zaledwie po dwóch-trzech miesiącach zdalnej edukacji.

${ }^{40}$ K. Makaruk, J. Włodarczyk, R. Szredzińska, Negatywne doświadczenia młodzieży $w$ trakcie pandemii. Raport z badań ilościowych, dz. cyt., s. 27. 
młodzieży. Fakt, że młodzi korzystają z Internetu częściej i intensywniej niż pokolenie ich rodziców (choć te różnice w ostatnich latach się zmniejszają), rodzi wiele nieporozumień oraz obaw.

Samo zdefiniowanie zjawiska nadużywanie czy uzależnienia od Internetu nastręcza dużych trudności, jako że wśród naukowców zajmujących się tym problemem nie ma zgody, co do jego istoty. Zazwyczaj wpisuje się je w szersze ramy uzależnień behawioralnych (uzależnień od czynności), choć nazewnictwo także bywa przedmiotem kontrowersji. Pewnym jest, że o uzależnieniu mówimy, gdy ilość czasu spędzanego w sieci wymyka się spod kontroli, a przebywanie w niej zaczyna mieć negatywny wpływ na relacje i funkcjonowanie społeczne młodego człowieka ${ }^{41}$.

W ostatnich latach wiele dyskusji poświęconych było kwestii, czy nadużywanie (uzależnienie) od Internetu powinno być wydzielone i wpisane do katalogów zaburzeń psychicznych takich jak amerykański DSM, czy europejski ICD. W opublikowanej w 2013 r. (i ciągle obowiązującej) klasyfikacji DSM-V uwzględniono jedynie „zaburzenie korzystania z gier internetowych" (ang. Internet Gaming Disorder). Rozpoznawane jest ono na podstawie dziewięciu kryteriów diagnostycznych wyodrębnionych na podstawie badań ${ }^{42}$. Jednocześnie osobne zdefiniowanie uzależnienia od gier internetowych i rozstrzygnięcia przyjęte w DSM bywają krytykowane przez czołowych badaczy ${ }^{43}$.

Ponieważ trudno prosto zdefiniować to zjawisko, trudno je także zmierzyć. W przeciwieństwie do omawianych wyżej zagrożeń, nie wystarczy bowiem zadać pytania o zaistnienie jakiejś sytuacji online. Nie można też odwołać się jedynie do kryterium czasu spędzanego w sieci. Zazwyczaj trzeba posłużyć się specjalnie przygotowanym testem psy-

41 S. Wójcik, Korzystanie z internetu przez polska młodziė - studium metoda teorii ugruntowanej. Wyniki badania EU NET ADB, „Dziecko krzywdzone. Teoria, badania, praktyka", 2013 tom 12 nr 1, s. 13-33.

42 N. M. Petry, C.P. O'Brien, Internet gaming disorder and the DSM-5. "Addiction" 2013, tom 108 nr 7, s. 1186-1187.

43 D. J. Kuss, M. Griffiths, H.M. Pontes, Chaos and confusion in DSM-5 diagnosis of Internet Gaming Disorder: Issues, concerns, and recommendations for clarity in the field. "Journal of behavioral addictions”, 2017 tom $6 \mathrm{nr}$ 2, s. 103-109. doi: 10.1556/2006.5.2016.062. 
chologicznym, który składa się z szeregu pytań odwołujących się do różnych symptomów nadużywania Internetu, takich jak zaniedbywanie obowiązków szkolnych bądź rodzinnych, objawy odstawienia, spędzanie większej ilości czasu niż zamierzonego, powracające myśli o Internecie itd. ${ }^{44}$.

W jednym z większych projektów badawczych dotyczących tego zagadnienia - europejskim badaniu EU NET ADB z 2012 roku posłużono się adaptacją testu IAT (Internet Addiction Test) Kimberly Young ${ }^{45}$. Odpowiadając na szereg pytań dotyczących korzystania z Internetu, można w nim uzyskać od 0 do 100 punktów. Od 70 punktów wzwyż klasyfikowano respondentów jako zdradzających objawy nadużywania, a od 40 do 69 punktów jako należących do grupy ryzyka. W Polsce w badaniu brała udział reprezentatywna próba uczniów klas trzecich gimnazjów (PAPI, N=1978). Wyniki sytuowały nasz kraj w połowie stawki i blisko średniej europejskiej. 1,3\% uczniów miało objawy uzależnienia od Internetu, a $12 \%$ było w grupie ryzyka. Skala uzależnienia była nieco większa wśród chłopców, niż wśród dziewcząt, ale różnice te nie były znaczące ${ }^{46}$.

Podobną metodologię (ten sam test i kryteria) zastosowano w badaniach powtórzonych w 2018 roku na zlecenie Funduszu Rozwiązywania Problemów Hazardowych ${ }^{47}$ na reprezentatywnej próbie 1017 uczniów w wieku 12-17 lat. Tym razem nasilone objawy uzależnienia wykazało $0,5 \%$ a w grupie ryzyka znajdowało się $11,4 \%$. Trzeba przy tym pamiętać, że próba obejmowała także młodsze nastolatki, a problem ten w większym stopniu dotyczy młodzieży starszej. Według cytowanego badania osoby, które wykazują objawy nadużywania Internetu, istotnie częściej mają kontakt z niebezpiecznymi treściami w sieci, w tym dotyczącymi okaleczania się i sposobów popełniania

44 K. Makaruk, S. Wójcik, Nadużywanie Internetu przez młodzież. Wyniki badania EU NET ADB, „Dziecko krzywdzone. Teoria, badania, praktyka”, 2013. 12.1: 35-48.

45 K. S. Young, Internet Addiction Test (IAT), Wood Dale 2016.

46 Tamże.

47 K. Makaruk, J. Włodarczyk, P. Skoneczna, Problematyczne u̇̇ywanie Internetu przez młodziė̇. Raport z badań, Warszawa, 2019. 
samobójstwa, a także istotnie częściej podejmują zachowania autoagresywne. Istotnie rzadziej natomiast spędzają czas offline - aktywnie uprawiając sport, czytając książki lub grając w gry planszowe. Projekt identyfikował także czynniki ryzyka oraz czynniki ochronne. Te pierwsze to przede wszystkim: odczuwanie silnego stresu szkolnego, doświadczanie przemocy rówieśniczej, negatywny stosunek do szkoły. Do czynników ochronnych należą: wsparcie ze strony rodziny, rówieśników i nauczycieli, prowadzenie przez rodziców rozmów z dzieckiem na temat bezpieczeństwa w Internecie, zainteresowanie rodzica aktywnością dziecka online oraz regularne poświęcanie przez dziecko czasu na hobby niezwiązane z mediami elektronicznymi. Potwierdza to obserwacje, że nadużywanie Internetu jest problemem złożonym, którego w zasadzie nie można rozpatrywać, abstrahując od kontekstu systemu rodzinnego, szkolnego, relacji z rówieśnikami i z rodzicami. Często trudno zresztą rozróżnić, czy problematyczne używanie Internetu jest przyczyną problemów społecznych czy na odwrót - zazwyczaj na pewnym etapie dochodzi do swoistego sprzężenia zwrotnego (błędnego koła).

Wobec złożoności samego zjawiska nie jest również prosta profilaktyka i interwencja w tym zakresie. Często niezbędna jest tu wiedza i praktyka psychologiczna. Z pewnością ważne jest kształcenie pedagogów i psychologów pracujących w placówkach edukacyjnych i poradniach. Kursy i różne formy kształcenia dla profesjonalistów oferują organizacje pozarządowe m.in. Fundacja Praesterno ${ }^{48}$, Fundacja Dajemy Dzieciom Siłę i Fundacja „Dbam o mój zasięg”49. Ta ostatnia organizacja zajmuje się kompleksowo tematem uzależnień elektronicznych - prowadzi szkolenia, badania, upowszechnia wiedzę na ten temat. Opracowała również pakiety edukacyjne dla uczniów w różnych grupach wiekowych pod wspólną nazwą „Fonolandia”. Z kolei Fundacja Dajemy

48 Fundacja Praesterno - szkolenia z zakresu uzależnień behawioralnych dostępne pod adresem https://uzaleznieniabehawioralne.praesterno.pl/ (dostęp: 15.07.2021 r.).

49 Fundacja Dbam o mój zasięg. Internet: https://dbamomojzasieg.pl (dostęp: 15.07.2021 r.). 
Dzieciom Siłę opracowała scenariusze lekcyjne „Dzień z życia”50, które mają za zadanie skłonić do refleksji na temat równowagi życia online i offline. Doświadczenia pokazują jednak, że profilaktyka w tym obszarze jest zadaniem trudnym. Utyskiwania na nadmiar czasu spędzanego z ekranami przez „dzisiejszą młodzież” są czymś tak powszechnym, że uczniowie nie są skłonni do podejmowanie tego tematu, nawet jeśli jest on rzetelnie przygotowany. Z pewnością ważną strategią jest praca z rodzicami, aby nie tylko wychowywali swoje dzieci w zakresie kontroli czasu i zaangażowania w sieci, ale także podejmowali refleksję nad własnym życiem w sieci i starali się oddziaływać poprzez własny przykład. Niedawną akcją opierającą się na tych założeniach była kam-

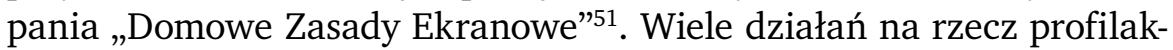
tyki uzależnień od czynności, w tym od Internetu finansowanych jest z Funduszu Rozwiązywania Problemów Hazardowych. Wiele informacji o wynikach tych projektów zawiera serwis „Uzależnienia behawioralne"52 prowadzony przez Fundację Studio Psychologii Zdrowia.

\section{Podsumowanie i implikacje pedagogiczne}

Pandemia COVID-19, która gwałtownie przyspieszyła cyfryzację życia społecznego i przeniosła życie zawodowe, towarzyskie, a nawet rodzinne do Internetu może być traktowana jako globalne domknięcie wielkiej cyfrowej rewolucji trwającej od przełomu XX i XXI wieku ${ }^{53}$. Jest to z pewnością dobry moment, aby zastanowić się nie tylko nad dobrodziejstwami, jakie przynosi nam globalna sieć, ale także aby zmierzyć

50 Dzień z życia. Scenariusz zajęć, Fundacja Dajemy Dzieciom Siłę. Internet: https://www.edukacja.fdds.pl/course/view.php?id=175\#section-2 (dostęp: 15.07.2021 r.).

51 Domowe Zasady Ekranowe, Fundacja Dajemy Dzieciom Siłę. Materiały dostępne: Internet: www.domowezasadyekranowe.fdds.pl (dostęp: 15.07.2021 r.).

52 Uzależnienia behawioralne, Fundacja Studio Psychologii Zdrowia, Internet: https://www.uzaleznieniabehawioralne.pl (dostęp: 15.07.2021 r.).

53 L. Hantrais i in. Covid-19 and the digital revolution, „Contemporary Social Science", 2021 tom 16 nr 2, s. 256-270. https://doi.org/10.1080/21582041.2020 .1833234 . 
się wreszcie z negatywnymi zjawiskami, z jakimi borykają się od lat młodzi ludzie w środowisku internetowym.

Niniejszy artykuł zakreślił dość ogólnie obszary, w których możemy mówić o zagrożeniach, oraz zaprezentował te z nich, które najczęściej poruszane są w debacie naukowej i pedagogicznej. We wszystkich czterech omówionych przypadkach mamy już zagraniczną i polską literaturę naukową, która opisuje i diagnozuje te zagrożenia. Znamy ich skalę, która jest niebagatelna, ponieważ dotyczy tysięcy młodych ludzi i znamy ich skutki, które nierzadko są bardzo poważne. Najważniejsze ustalenia podsumowuje tabela 2 .

Ciągle jednak zbyt mało mamy inicjatyw profilaktycznych, które mogłyby zapobiegać tym zjawiskom oraz miejsc, w których młodzi ludzie mogą szukać pomocy. Wiele wymienionych w artykule organizacji i instytucji stara się poprawić tę sytuację i wielu pedagogów podnosi swoje kwalifikacje, aby móc sprostać omówionym tu wyzwaniom. Problem jednak jest złożony i wymaga wieloaspektowej interwencji. Nie tylko przekazywania młodzieży informacji o potencjalnych ryzykach, ale nauki kompetencji do radzenia sobie z nimi oraz systemu pomocy, który odpowiednio reagowałby na incydenty wykrywane w środowisku szkolnym. Ważne jest myślenie przez pryzmat standardów, które powinna spełniać placówka edukacyjna w zakresie zapewnienia młodzieży szeroko rozumianego bezpieczeństwa online ${ }^{54}$. Uczniowie powinni nie tylko wiedzieć, że takie zjawiska istnieją, ale mieć jasność do kogo zwrócić się o pomoc, kiedy będą mieli jakiś problem. Dotyczy to szczególnie zjawiska przemocy rówieśniczej, które jest powszechne, a w którym pokrzywdzone dziecko często czuje się osamotnione.

54 Por. Bochenek M. i in. Standard bezpieczeństwa online placówek oświatowych, red. J. Lizut, A. Wrońska. Warszawa 2018. Internet: https://akademia.nask. pl/publikacje/ost_Standard_bezpieczenstwa_online_placowek_oswiatowych.pdf

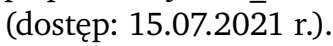




\section{Tabela 2}

\section{Zestawienie omówionych zagrożeń}

\begin{tabular}{|c|c|c|c|c|}
\hline & $\begin{array}{c}\text { Istota } \\
\text { zagrożenia }\end{array}$ & $\begin{array}{l}\text { Typ zagrożenia } \\
\text { wg typologii } 4 \mathrm{C}\end{array}$ & $\begin{array}{l}\text { Potencjalne } \\
\text { skutki }\end{array}$ & $\begin{array}{c}\text { Skala } \\
\text { występowania } \\
\text { w Polsce }\end{array}$ \\
\hline $\begin{array}{l}\text { Kontakt } \\
\text { z pornografią }\end{array}$ & $\begin{array}{l}\text { Narażenie na } \\
\text { kontakt z mate- } \\
\text { riałami uka- } \\
\text { zującymi seks } \\
\text { w uprzedmioto- } \\
\text { wiony sposób, } \\
\text { często z użyciem } \\
\text { przemocy }\end{array}$ & $\begin{array}{l}\text { Dziecko jako } \\
\text { odbiorca treści } \\
\text { seksualnych } \\
(\text { contact }- \text { sex })\end{array}$ & $\begin{array}{l}\text { Fałszywe prze- } \\
\text { konania i wiedza } \\
\text { o ludzkiej } \\
\text { seksualności, } \\
\text { lęki, zaburzenia, } \\
\text { ryzyko stosowa- } \\
\text { nia przemocy } \\
\text { seksualnej }\end{array}$ & $\begin{array}{l}\text { Od } 29 \% \text { do } 43 \% \\
\text { dzieci ma kontakt } \\
\text { z pornografią }\end{array}$ \\
\hline Seksting & $\begin{array}{l}\text { Przesyłanie } \\
\text { intymnych zdjęć } \\
\text { i filmów mogące } \\
\text { prowadzić do } \\
\text { wycieku tych } \\
\text { materiałów }\end{array}$ & $\begin{array}{l}\text { Dziecko jako } \\
\text { uczestnik działań } \\
\text { seksualnych (con- } \\
d u c t-s e x)\end{array}$ & $\begin{array}{l}\text { Narażenie na } \\
\text { uwodzenie i wy- } \\
\text { korzystywanie } \\
\text { seksualne online, } \\
\text { potencjalne gene- } \\
\text { rowanie porno- } \\
\text { grafii dziecięcej }\end{array}$ & $\begin{array}{l}\text { Od } 15 \% \text { do } 34 \% \\
\text { młodzieży } \\
\text { otrzymuje takie } \\
\text { materiały, od } 5 \% \\
\text { do } 15 \% \text { je wysyła }\end{array}$ \\
\hline Cyberprzemoc & $\begin{array}{l}\text { Przemoc rówie- } \\
\text { śnicza z użyciem } \\
\text { mediów elektro- } \\
\text { nicznych }\end{array}$ & $\begin{array}{l}\text { Dziecko jako } \\
\text { uczestnik działań } \\
\text { agresywnych } \\
\text { (conduct - aggres- } \\
\text { sion) }\end{array}$ & $\begin{array}{l}\text { Ryzyko depresji, } \\
\text { lęków społecz- } \\
\text { nych, obniżonego } \\
\text { poczucia własnej } \\
\text { wartości, uzależ- } \\
\text { nień }\end{array}$ & $\begin{array}{l}\text { Zależnie od } \\
\text { definicji od } 9 \% \\
\text { do } 40 \% \text { uczniów } \\
\text { pada ofiarą cy- } \\
\text { berprzemocy }\end{array}$ \\
\hline $\begin{array}{l}\text { Nadużywanie } \\
\text { Internetu }\end{array}$ & $\begin{array}{l}\text { Nadmierne } \\
\text { zaangażowanie } \\
\text { w korzystanie } \\
\text { z mediów elektro- } \\
\text { nicznych skutku- } \\
\text { jące negatywny- } \\
\text { mi efektami dla } \\
\text { jednostki }\end{array}$ & Poza typologią & $\begin{array}{l}\text { Negatywny } \\
\text { wpływ na } \\
\text { całokształt } \\
\text { funkcjonowania, } \\
\text { zaburzenia lęko- } \\
\text { we, depresyjne }\end{array}$ & $\begin{array}{l}\text { Ok. } 1 \% \text { wykazu- } \\
\text { jący silne objawy, } \\
\text { ok. } 10 \% \text { w grupie } \\
\text { ryzyka }\end{array}$ \\
\hline
\end{tabular}

Źródło: opracowanie własne. 
Idealnie byłoby, gdyby temat bezpieczeństwa w sieci nie pojawiał się w oderwaniu od codziennego życia jako odległe i groźne niebezpieczeństwo, ale był łączony z codziennym doświadczeniem i innymi tematami. Przykładowo temat pornografii i sekstingu może być związany $\mathrm{z}$ kwestiami relacji omawianych podczas zajęć WDŻ, kwestie związane z cyberprzemocą dotyczą zarówno kultury wypowiedzi (język polski), jak i kwestii integracji klasy (godziny wychowawcze). Z kolei problem nadużywania i zrównoważonego korzystania $\mathrm{z}$ sieci jest bezpośrednio związany z tematami zdrowotnymi poruszanymi choćby na lekcjach biologii.

Należy również pamiętać o ścisłym powiązaniu rzeczywistości młodych ludzi online i offline. Metaanalizy wielu badań pokazały, że dzieci zagrożone ubóstwem, przemocą w rodzinie, wykorzystaniem seksualnym są również bardziej podatne na różnego rodzaju zagrożenia online, a ich skutki są dla nich bardziej dotkliwe. Jednocześnie ci młodzi ludzie, którzy mają oparcie w swoim środowisku domowym i szkolnym, mają niezagrożone poczucie własnej wartości oraz są wyposażeni w podstawowe kompetencje cyfrowe mogą uniknąć wielu opisanych tu ryzyk, a w przypadku ich zaistnienia, nie ponosić negatywnych konsekwencji ${ }^{55}$. Jest to związane z psychologiczno-pedagogiczną koncepcją rezyliencji (ang. Resilience), którą zdefiniować można jako „wielowątkowy proces, za pomocą którego dzieci nabywają umiejętności korzystania z wewnętrznych i zewnętrznych zasobów po to, by osiągnąć dobre przystosowanie (pozytywną adaptację), pomimo [...] trudności" ${ }^{56}$. Przebieg tego procesu zależy właśnie od kontekstu społecznego, warunków rodzinnych, społeczności, w tym społeczności szkolnej oraz kompetencji $\mathrm{m}$. in. $\mathrm{w}$ radzeniu sobie ze trudnymi sytuacjami ${ }^{57}$. Przy

55 M. Stoilova, S. Livingstone, R. Khazbak, Investigating Risks and Opportunities for Children in a Digital World: A rapid review of the evidence on children's internet use and outcomes, Florencja 2021.

56 A. Borucka, K. Ostaszewski, Czynniki i procesy resilience wśród dzieci krzywdzonych. „Dziecko Krzywdzone. Teoria, badania, praktyka”, 2012 tom $11 \mathrm{nr}$ 3, s. 7-26, s. 9.

57 L. Rew, Sh. Horner, Youth resilience framework for reducing health-risk behaviors in adolescents, "Journal of pediatric nursing", 2003 tom 18 nr 6, s. 379-388. https://doi.org/10.1016/S0882-5963(03)00162-3. 
czym rezyliencji nie należy rozumieć jedynie jako zewnętrznie zdefiniowanego zestawu cech, który determinuje podatność na zagrożenia. Tę swoistą „społeczną odporność” można i należy również stymulować. Istnieją programy interwencyjne oparte o koncepcję rezyliencji, mające na celu wzmocnienie czynników chroniących daną jednostkę ${ }^{58}$. Jest to szczególnie istotne przy zagadnieniu zagrożeń internetowych, których - biorąc pod uwagę masowość - bardzo trudno uniknąć. Powinniśmy skupić się na tym, aby dzieci mające kontakt ze szkodliwymi treściami albo padające ofiarą wrogich zachowań nie zostawały z tymi problemami same, wiedziały co zrobić w tej sytuacji i mogły znaleźć pomoc w domu, w szkole i w całym swoim społecznym otoczeniu.

\section{Bibliografia}

Amundsen, Rikke. 2019. "Kind of like making porn of yourself: understanding sexting through pornography". Feminist Media Studies tom 19 nr 4: 479494. https://doi.org/10.1080/14680777.2018.1494617.

Barlińska, Julia. Dominik, Lalak. Anna, Szuster. „Jak skutecznie ograniczyć cyberprzemoc rówieśniczą? - o efektywności metod aktywizujących kompetencje społeczne ze szczególnym uwzględnieniem empatii". Dziecko Krzywdzone. Teoria, badania, praktyka tom $17 \mathrm{nr} 1$ (2018): 68-95.

Bochenek, Marcin i in. Nastolatki 3.0, Raport z ogólnopolskiego badania uczniów, red. Marcin Bochenek, Rafał Lange. Warszawa: PIB NASK, 2019.

Bochenek Marcin i in. Standard bezpieczeństwa online placówek oświatowych, red. Jolanta Lizut, Agnieszka Wrońska. Warszawa: NASK i WSP im. Korczaka, 2018. Internet: https://akademia.nask.pl/publikacje/ost_ Standard_bezpieczenstwa_online_placowek_oswiatowych.pdf (dostęp: 15.07.2021 r.).

Borucka, Anna; Krzysztof Ostaszewski, „Czynniki i procesy resilience wśród dzieci krzywdzonych". Dziecko Krzywdzone. Teoria, badania tom $11 \mathrm{nr} 3$ (2012): 7-26.

58 J. Haase. The adolescent resilience model as a guide to interventions. "Journal of Pediatric oncology nursing", 2004 tom 21 nr 5, s. 289-299. https://doi. org/10.1177/1043454204267922. 
Bridges, Ana J., i in. 2010. "Aggression and sexual behavior in best-selling pornography videos: A content analysis update". Violence against women tom 16 nr 10: 1065-1085. https://doi.org/10.1177/1077801210382866.

Domowe Zasady Ekranowe, Fundacja Dajemy Dzieciom Siłę. Materiały dostępne: Internet: www.domowezasadyekranowe.fdds.pl (dostęp: 15.07.2021 r.).

Dziemidowicz E., J. Klocek, M. Wojtas, Rozumiem i wybieram. Jak korzystać z zasobów Internetu, aby sobie nie zaszkodzić?, Warszawa 2017. Internet: https://edukacja.fdds.pl/pluginfile.php/703/course/section/703/Rozumiem_i_wybieram_Jak_korzystac_z_zasobow_internetu_aby_sobie_nie zaszkodzic11-14_21̄122017_scenariusz_zajec.pdf (dostęp: 15.07.2021 r.).

Dzień z życia. Scenariusz zajęć, Fundacja Dajemy Dzieciom Siłę. Internet: https://www.edukacja.fdds.pl/course/view.php?id=175\#section-2 (dostęp: 15.07.2021 r.).

Fundacja Dbam o mój zasięg. Internet: https://dbamomojzasieg.pl (dostęp: 15.07.2021 r.).

Fundacja Praesterno - szkolenia z zakresu uzależnień behawioralnych dostępne pod adresem https://uzaleznieniabehawioralne.praesterno.pl/ (dostęp: 15.07.2021 r.).

Gola, Mateusz, Ewelina Kowalewska, Karol Szymczak, Analiza zmian częstotliwości brutalnych zachowań $w$ popularnych filmach pornograficznych publikowanych między 1995 a 2019 rokiem. Warszawa: Stowarzyszenie Twoja Sprawa, 2020.

Haase, Joan. 2004. "The adolescent resilience model as a guide to interventions". Journal of Pediatric oncology nursing tom $21 \mathrm{nr}$ 5: 289-299. https:// doi.org/10.1177/1043454204267922.

Hantrais, Lidia i in. 2021. Covid-19 and the digital revolution, „Contemporary Social Science" tom $16 \mathrm{nr} 2:$ :256-270. https://doi.org/10.1080/21582041.2 020.1833234. IMPACT (Interdyscyplinarny Model Przeciwdziałania Agresji i Cyberprzemocy Technologicznej), Fundacja Dajemy Dzieciom Siłę. Internet: impact.fdds.pl (dostęp: 15.07.2021 r.).

Internet: https://zdalnenauczanie.org/wp-content/uploads/2020/06/Badanie-zdalnenauczanie_org_prezentacja.pdf (dostęp: 15.07.2021 r.).

Izdebski, Zbigniew, Krzysztof Wąż. „Zdrowie seksualne i reprodukcyjne młodzieży". Zdrowie Publiczne i Zarządzanie tom $12 \mathrm{nr}$ 1. (2014): 44-45.

Kaczan, Radosław. Wójcik, Małgorzata. Monitorowanie i zwalczanie przemocy $w$ szkole RSQL, Uniwersytet SWPS. Internet: www.resql.pl (dostęp: 15.07.2021 r.). 
Katana, Katarzyna. „Prawne aspekty dobrowolnej aktywności seksualnej online podejmowanej przez małoletnich". Dziecko Krzywdzone. Teoria, badania, praktyka tom 19 nr 4 (2020): 126-144.

Kuss, Daria. Griffiths, Mark. Pontes, Halley. 2017. "Chaos and confusion in DSM-5 diagnosis of Internet Gaming Disorder: Issues, concerns, and recommendations for clarity in the field". Journal of behavioral addictions tom 6 nr 2: 103-109. DOI: 10.1556/2006.5.2016.062.

Kwaśnik, Anna. Seksting i nagie zdjęcia. Twoje dziecko i ryzykowne zachowania online, Warszawa: NASK PIB, 2019. Internet: https://kometa.edu.pl/ uploads/publication/975/d7d3_AA_,Sexting_i_nagie_zdjęcia”_poradnik_dla_rodziców.pdf?v2.8 (dostęp: 15.07.2021 r.).

Lim, Megan. Carrotte, Elise R. Hellard, Margaret E. 2016. “The impact of pornography on gender based violence, sexual health and well-being: what do we know?". J Epidemiol Community Health tom $70 \mathrm{nr}$ 1: 3-5. DOI: http:// dx.doi.org/10.1136/jech-2015-205453.

Livingstone, Sonia, Lesslie Haddon, Anke Görzig, Kjartan Olafsson. Final report, EU kids online II. London: London School of Economics (LSE): 2011. Internet: http://eprints.lse.ac.uk/39351/1/EU_kids_online_final_report_\%5BLSERO\%5D.pdf (dostęp: 15.07.2021 r.).

Livingstone, Sonia, Stoilova, Mariya. The 4Cs: Classifying Online Risk to Children. Leibniz Institut für Medienforschung, Hans-Bredow-Institut (HBI), Hamburg 2021. https://doi.org/10.21241/ssoar.71817. Internet: https:// www.ssoar.info/ssoar/bitstream/handle/document/71817/ssoar-2021livingstone_et_al-The_4Cs_Classifying_Online_Risk.pdf?sequence $=4$ \&isA llowed $=y \& \operatorname{lnk}$ name $=$ ssoar-2021-livingstone_et_al-The_4Cs_Classifying_ Online_Risk.pdf (dostęp: 15.07.2021 r.).

Makaruk, Katarzyna, Joanna Włodarczyk, Renata Szredzińska, Negatywne doświadczenia młodzieży $w$ trakcie pandemii, Raport z badań ilościowych. Warszawa: Fundacja Dajemy Dzieciom Siłę, 2020.1.

Makaruk, Katarzyna, Joanna Włodarczyk, Piotr Michalski, Kontakt dzieci i młodzieży z pornografią. Raport z badań, Warszawa: Fundacja Dajemy Dzieciom Siłę, 2017.

Makaruk, Katarzyna, Joanna Włodarczyk, Patrycja Skoneczna, Problematyczne używanie internetu przez młodzież. Raport z badań, Warszawa: Fundacja Dajemy Dzieciom Siłę, 2019.

Makaruk, Katarzyna, Szymon Wójcik. „Nadużywanie Internetu przez młodzież. Wyniki badania EU NET ADB”. Dziecko krzywdzone. Teoria, badania, praktyka tom 12 nr 1 (2013): 35-48. 
Poszwa, Kinga. Myślińska, Dominika. „Analiza zjawiska przemocy rówieśniczej - teoria i badania własne". Dziecko Krzywdzone. Teoria, badania, praktyka tom $19 \mathrm{nr} 4$ (2020): 12-25.

Peter, Jochen. Valkenburg, Patti M. "The use of sexually explicit internet material and its antecedents: A longitudinal comparison of adolescents and adults". Archives of Sexual behavior tom 40 nr 5 (2011): 1015-1025.

Petry, Nancy. O'Brien, Charles. "Internet gaming disorder and the DSM-5". Addiction, tom 108 (2013): 1186-1187.

Przeciwdziałanie zjawiskom patologii wśród młodzieży szkolnej. Informacje o wynikach kontroli, KNO-410103-00/2013. Nr ewi. 43/2014/P/13/068/ KNO. Warszawa: Najwyższa Izba Kontroli, 2014. https://www.nik.gov.pl/ plik/id,6956,vp,8803.pdf (dostęp: 15.07.2021 r.).

Ptaszek, Grzegorz i in. Zdalna edukacja - gdzie byliśmy, dokąd idziemy? Wstępne wyniki badania naukowego „Zdalne nauczanie a adaptacja do warunków społecznych $w$ czasie epidemii koronawirusa". Warszawa, 2020. DOI: 10.13140/RG.2.2.25737.67685.

Pyżalski, Jacek, Agresja elektroniczna i cyberbullying jako nowe ryzykowne zachowania młodzieży. Kraków: Oficyna Wydawnicza „Impuls”, 2012.

Pyżalski, Jacek, Elektroniczna agresja rówieśnicza - ustalenia empiryczne ostatniej dekady. W: Uzależnienia behawioralne $i$ zachowania problemowe młodzieży, red. Jolanta Jarczyńska. Bydgoszcz: Wydawnictwo Uniwersytetu Kazimierza Wielkiego, 2014.

Rew, Lynn. Horner, Sharon. 2003. "Youth resilience framework for reducing health-risk behaviors in adolescents". Journal of pediatric nursing tom 18 nr 6: 379-388. https://doi.org/10.1016/S0882-5963(03)00162-3.

Seksting. Scenariusz zajęć dla uczniów szkót ponadpodstawowych. Fundacja Dajemy Dzieciom Siłę, 2016. Internet: https://edukacja.fdds.pl/pluginfile.php/703/course/section/705/seksting_01_21112016_scenariusz.pdf?ti$\mathrm{me}=161904502853$ (dostęp: 15.07.2021 r.).

Smahel, David i in. EU Kids Online 2020: Survey results from 19 countries. EU Kids Online 2020. doi.org/10.21953/lse.47fdeqj01ofo. Internet: http:// eprints.lse.ac.uk/103294/1/EU_Kids_Online_2020_March2020.pdf (dostęp: 15.07.2021 r.).

Spotlight on adolescent health and well-being. Findings from the 2017/2018 Health Behaviour in School-aged Children (HBSC) survey in Europe and Canada. International report. Volume 2. Key data. Red. Jo Inchley i in. Copenhagen: WHO Regional Office for Europe, 2020. https://apps.who.int/ 
iris/bitstream/handle/10665/332091/9789289055000-eng.pdf (dostęp: 15.06.2021 r.).

Stoilova, Mariya. Livingstone, Sonia. Khazbak, Rana. Investigating Risks and Opportunities for Children in a Digital World: A rapid review of the evidence on children's internet use and outcomes. Innocenti Discussion Paper 202003. Florencja: UNICEF Office of Research - Innocenti, 2021.

Stowarzyszenie Twoja Sprawa. Strona Internetowa: https://opornografii.pl (dostęp: 15.07.2021 r.).

Tomczyk, Łukasz. Materiały dotyczace seksu i zjawisko sekstingu. W: Jacek Pyżalski, Aldona Zdrodowska, Łukasz Tomczyk, Katarzyna Abramczuk. Polskie badanie EU Kids Online 2018. Najważniejsze wyniki i wnioski, 137-154. Poznań: Wydawnictwo Naukowe Uniwersytetu im. Adama Mickiewicza, 2019.

UNICEF, The State of the World's Children 2017: Children in a digital world, New York: UNICEF, 2018.

Uzależnienia behawioralne, Fundacja Studio Psychologii Zdrowia, Internet: https://www.uzaleznieniabehawioralne.pl (dostęp: 15.07.2021 r.).

Włodarczyk, Joanna. "Zagrożenia związanie z korzystaniem z Internetu przez młodzież.

Wojtasik, Łukasz. „Seksting wśród dzieci i młodzieży”. Dziecko krzywdzone. Teoria, badania, Praktyka tom 13 nr 2 (2014): 79-98.

Wolak, Janis. Finkelhor, David. "Sexting: A typology.", 2011. "Durham, NH: Crimes against Children Research Center", 2011. Internet: https://scholars.unh.edu/cgi/viewcontent.cgi?article $=1047 \&$ context $=$ ccrc $\quad$ (dostęp: 15.07.2021 r.).

Wójcik, Szymon. „Korzystanie z internetu przez polską młodzież - studium metodą teorii ugruntowanej. Wyniki badania EU NET ADB". Dziecko krzywdzone. Teoria, badania, praktyka tom $12 \mathrm{nr} 1$ (2013) 12.1: 13-33.

Wójcik, Szymon. Makaruk, Katarzyna. Seksting wśród polskiej młodzieży. Wyniki badania ilościowego, Warszawa 2014. Internet: https://fdds.pl/_Resources/Persistent/c/c/8/f/cc8fee410093693294ae8b7fbf39b2c0d9322b41/Wojcik_Makaruk_eksting_wsrod_polskiej_mlodziezy.pdf (dostęp: 15.07.2021 r.).

Wyniki badania EU NET ADB. Dziecko krzywdzone. Teoria, badania, prakty$k a$, tom $12 \mathrm{nr} 1$ (2013): 49-68.

Young, Kimberly S. Internet Addiction Test (IAT). Wook Dale: Stoelting, 2016. 